\title{
PROBLEM OF UROGENITAL MIXED INFECTIONS IN REPRODUCTIVE AGED WOMEN IN CURRENT GYNECOLOGY
}

\author{
LITERATURE REVIEW
}

\section{N.Y. BYSAHA \\ PhD, associate professor of the Obstetrics and Gynecology Department, Medical Faculty of the Uzhgorod National University obstetrician-gynecologist of the gynecological department, Uzhgorod Regional Hospital, Uzhgorod ORCID: 0000-0001-6226-7294 \\ 0.0. KORCHYNSKA \\ MD, professor of the Obstetrics \\ and Gynecology Department \\ Medical Faculty of the Uzhgorod \\ National University, Uzhgorod \\ ORCID: 0000-0001-7265-4829 \\ Contacts: \\ Nataliya Y. Bysaha \\ Uzhgorod Regional Hospital \\ 88015, Mynaiska str. 71, \\ Uzhgorod, Ukraine \\ Tel.: + 38 (0312) 662316 \\ email:your_natali@yahoo.com}

\section{INTRODUCTION}

According to current researchers data more than 60 phenotypes of microorganisms may be present in vaginal microbiocenosis, however, their set is relatively stable if woman remains healthy during a considerable period of time. According to the WHO experts conclusions the sexually transmitted infections (STI) are the cause of $60 \%$ pelvic inflammatory diseases (PID), whereas chlamydiosis, gonorrhea and trichomoniasis are leading in this list (65-70\% of PID cases) [2]. PIDs are observed in $38-67 \%$ of reproductive aged women and frequently are characterized by a latent progression that stipulates the difficulties in their timely diagnostics.

\section{ETIOLOGICAL FACTORS OF INFLAMMATORY PROCESS OF REPRODUCTIVE ORGANS}

Involvement of all pelvis organs into the pathological process with high degree of probability of the adhesive changes that require the adequate correction and rehabilitation therapy is typical for the "silent" inflammatory genital organ diseases. PID is a general problem related to a wide range of disorders of female reproductive and sexual health caused by both a list of the reasons for their appearance and formation of a spectrum of complications, even after the therapy delivery $[4,19]$.

Recent studies demonstrate a growth in PIDs occurrence caused by STI. About 500 millions of new events of syphilis, gonorrhea, chlamydiosis, trichomoniasis in reproductive aged men and women are detected annually $[5,26]$. Microbe agents or their various associations play the leading role in the PID occurrence from the beginning of sexual life. Among the etiological factors inflammatory processes of reproductive system are multi-resistant factors or L-forms (protozoare, bacteria, fungi, viruses) with modified biological properties in the numerous $\mathrm{mi}-$ crobe association are found more frequently, partially due to the non-systemic and unjustified administration of antibiotics, hormonal preparations, cytokines etc. [6, 27].

Upper genital organs (i.e. uterus, uterine tubes) are covered with a soft and sensitive cylindrical epithelium that borders with vagina cavity, whose epithelium is more resistant to infection. Uterine cervix is a kind of a frontier between the two epi- thelia (i.e. flat and cylindrical ones) [28]. Mucus is produced in the uterine cervical canal being enriched with proteases and bactericide enzymes working as the protective filter, first and foremost, against the microbes that enter together with spermatozoids the upper regions of genital organs. The above barriers are transparent for some factors (i.e. chlamydia, gonococci, mollicutes) capable of entering the upper regions of genital organs in a transcanalicular way, as well as through the emdometrium, more probably, during the instrumental interventions [7, 29].

\section{FAVORABLE FACTORS FOR EXACERBATION OF GENITAL AND URINARY INFLAMMATORY DISEASES}

It should be noted that the risks of recrudescence of urogenital inflammatory diseases increase from the $25^{\text {th }}$ to the $6^{\text {th }}$ days of the menstrual cycle. This period before and during menstruation should be deemed critical and favorable for infection dissemination into the upper regions of genital organs, urethra, urinary bladder and kidneys. The menstrual discharges collected inside the vagina favor formation of a passive medium for activating the conditionally pathogenic flora and realizing the aggressive properties of agents. Endometrium defects and menstrual blood reflux cause the aerobic and anaerobic bacteria dissemination into the upper regions of the genital tract and urinary system $[8,30]$.

It is a well-known fact that the urethra, urinary bladder and lower third part of the renal ducts have a similar embryonic origin and are developing from a single urogenital sinus as two functionally and anatomically congenial systems. Just for this reason, damaging the chain of one of these systems is often related to the functional disorders and, possibly, to those of other system, especially in the case when the progress of the inflammatory disease is due to the mixed infection [31-33].

It is assumed that initially the inflammatory process is initiated by one microbe factor only, and this is accompanied by a change in the local immune protection and creation of the favorable conditions for other microorganisms superimposing. Gonococci, chlamydia and trichomonads are the main "initiators" of the above changes. The leading role in forming the disor- 
ders in the mucous membrane protection mechanisms in the uterine cervical canal, urethra and urinary bladder is played by the changes in the local immunity provided the infection generalization [34-36].

Activity of the infection factors depends on a number of indices, i.e. the biological characteristics of bacteria, their local and generalized effect on the human organism, as well as on the direct relationships between the host and the infection agent taking place in each particular case. As known, the chlamydia and mollicutes have a stimulating action on the lymphocytic reactions stipulating the progressive fibrinosis development. In contrary, the classical microbe agents, e.g., gonococci, trichomonads and other bacteria, stimulate the development of the coarse pyogenic processes [9, 37, 38]. In case of infecting by the mycoplasma, ureaplasma and/or gardnerella, the infection inflammatory process could proceed at a certain agent concentration and disorders in the microorganism immune protection only.

The microbe antagonism explains a protective role played by the vaginal microbes (Döderlein bacillus). Microorganism synergism allows certain infectious agents to potentiate other microorganisms' virulence that grows with time. This relates first of all the gardnerella and the anaerobes [10].

\section{MECHANISMS OF THE UTERINE APPENDAGES INFECTION}

Four basic pathogenic mechanisms of infecting the uterine annexes and those of the pathogenic and conditionally pathogenic agent entrance to the upper regions of genetic organs are known now. The most prevalent mechanism of the microbe agent entrance to the upper regions of genetic organs is the transcanicular one (i.e. through the uterine cervical canal along the endometrium surface onto the uterine tubes and ovaries) [9].

Schematically, the model of the infectious agent(s) dissemination into the upper regions of genetic organs was described by J. Wasserheit [5] as follows:

the disease begins from infecting the uterine cervical canal (mainly by Chlamydia trachomatis, Neisseria gonorrhoeae, mollicutes or by their association);

3 the increase of a disproportion between the lactobacilli and microorganisms inside the vagina and the uterine cervical canal towards the numerical superiority of the latter is observed; s the natural flora of vagina uterine cervical canal is noticed to be expelled with simultaneous predominance of the parasitic activity of microorganisms;

s the final of the genuine cervical pathogenesis of infection generalization is characterized by a numerical growth of microorganisms, who are the inflammatory process factors to such a qualitative limit, when the genuine agent is able to enter freely the upper regions of genetic organs, i.e. the endometrium, uterine tubes, ovaries and urinary bladder; all the genital tract regions and, probably, those of excretory system and, over time, the parietal peritoneum, become gradually damaged.

The transcanicular mechanism of infection dissemination into the upper regions of genetic organs is observed most frequently in young females having numerous sexual partners. This is explained by the fact that young females have a cer- tain deficiency of the local factors of immunological protection against infection and the wider zone of the uterine cervix cylindrical epithelium stipulating the Chlamydia trachomatis and Neisseria gonorrhoeae colonization [11, 39].

\section{VAGINAL MICROBIOCENOSIS}

According to the nowadays visions, the vaginal microecology is considered the aggregate of the residential and transitory micloflora in the dynamical equilibrium state. A considerable variety of microorganism species represented mainly by Lactobacillus spp. (93-97\%). Among them the peroxide-producing Lactobacillus provides the $3.8-4.5 \mathrm{pH}$ level of the vaginal secret (one of the factors of the colonization vaginal resistance) and are of particular importance, is an essential specific feature of the vaginal microbiocenosis [12].

The quantitative and qualitative compositions of the vaginal microflora are susceptible to both the exogenic and endogenic influence (i.e. violation of the endocrine system activity, invasive curing and diagnostic gynecological manipulations, the use of the systemic and local antimicrobial and other medications). Reduction of the quantitative Lactobacillus spp. content leads to the vaginal dissemination of the microorganisms (mainly anaerobic) present in small quantities and/or vaginal colonization by the conditionally pathogenic transitory microorganisms that, respectively, could be manifested by the bacterial vaginosis (BV) or Candida (or non-specific) vaginitis [13].

Now the convincing evidences of the relationship between the BV-associated microorganisms and the development of the PID after the invasive gynecological curative and diagnostic manipulations and the vaginal residual limb phlegmon after the abdominal hysterectomy have been obtained [14]. The results of the three randomized studies have demonstrated the reduction of the PID development in the females with BV at administering the anti-anaerobic preparations prior to the surgical pregnancy interruption. At the same time, the number of convincing data on the advantages and shortcomings of BV treatment prior to other gynecological manipulations is small [15].

The etiology of the non-specific vulvovaginitis is most frequently related to $E$. coli, Staphylococcus spp., Klebsiella spp., Proteus spp., Enterococcus faecalis and other conditionally pathogenic microorganisms that could be partially found in the vaginal normobiocenosis. Realization of the pathogenic properties of the above microorganisms is favored by various endogenic and exogenic factors (immunological reactivity reduction, effect of chemical, thermal and other factors, violation of principles of personal and/or sexual hygiene, specific character of the sexual practice etc.) [40-42].

Today more frequently detected conditions is a chronic disease progression characterized by a moderate hyperemia and edema, as well as by the petechial hemorrhages at the vaginal mucous membrane. The colcoscopic study allows the moderate signs of inflammatory process, the focal or diffuse vaginal mucous membrane hyperemia and the epithelium infiltration to be detected. However, one should keep in mind that it is necessary to exclude the STIs and other vaginal infections, as well as to carry out the bacteriological studies to find the non-specific vaginitis etiology. 
Among the females of reproductive age the urinary tract infections (UTI) are detected dozens times more frequently as compared to males [16]. According to WHO, the female reproductive age is $15-49$ for the countries with low birth rate and $15-45$ for those with high birth rate.

A list of etiologic factors of the UTI inflammatory processes keeps on replenishing, varying dependent of the age peculiarities, dissemination character and the macromicroorganism(s) relations scenario uniqueness (the "vis-àvis" phenomenon) taking place in each case individually. The role of the urogenital infections in the female uretrites and cystites etiology is indisputable. The viruses (adenoviruses, enteroviruses, herperic group viruses, parainfluenza viruses), protozoans (Trichomonas vaginalis), helmints, fungi, intracellular agents (Chlamydia trachomatis, Ureaplasma urealiticum, Mycoplasma genitalium, Mycoplasma hominis) and the zoonotic infection agents may also be the etiologic agents.

In females of reproductive age the ascendant infecting way is prevails, often associated with the sexually transmitted infection agents and the conditionally pathogenic microflora [17]. It should be noted that the genital and the urinary organs are developing in the embriogenesis process from a single germinal layer (mesoderms), they have a close anatomic and physiological connection, common blood supply and lymphatic system. The urinary tract, urinary bladder and ureters, like the reproductive system organs, are the target organs for the sex hormone action [18].

Microecosystem of the genital and urinary tracts depends to a great extent on the morphofunctional and anatomical peculiarities of the female organism. The vagina self-cleaning system functions for a long time, i.e. from the teenage years till the postmenopause period. The vaginal and uterine epithelium in different physiological periods of female's life is affected by the sex hormones and changes qualitatively according to their concentration in the blood serum. Estrogen favors active growth and maturing of a multi-layer glycogenenriched flat epithelium. Under the influence of estrogens the cervical mucous plug is saturated by the bactericide enzymes and is capable of performing the function of a barrier, a kind of a filter that prevents pathogenic agent (specific and nonspecific infection) dissemination into the upper regions of the urogenital tract and the inflammatory process generalization. Like the estrogens, the androgens also have their proliferative effect on the vaginal epithelium.

Progesterone decelerates the multi-layer flat epithelium maturing. In case of the increase of this hormone concentration in blood, the cells mature till the interim layer only. Due to progesterone impact the multi-layer flat epithelium cytolysis and desquamation occur with glycogen release to the vaginal gap. Under the influence of the cellular ferments the glycogen produces sugars, maltose and dextrose making a nutrient medium for lactobacillus.

Lactobacilli are the polymorphous Gram-positive bacteria with specific high antagonistic ability that allows the active reproduction of the conditionally pathogenic flora to be prevented. The acid vaginal medium, as well as the products of the lactobacillus vital activity (i.e. hydrogen peroxide, lisocyme and other glycolytic enzymes), prevent the pathogenic microorganisms development. Lactobacilli stimulate the phagocyte activity of neutrophiles and macrophages, production of interferons and secretory immunoglobulins, supporting activity of the local immune protection components [20]. The genital system inflammatory diseases with still high frequency of occurrence in the gynecological pathology are closely related to the dysbiotic disorders in the vaginal biotope, and this promotes the infectious microorganism ascendant translocation to the organs of both upper regions of genital system and the urinary one.

Among the diseases in pregnant women that result in the fetus and newborn infection, the following ones are especially noteworthy: the urogenital infections clinically manifested in a form of the colpitis, cervicitis, chronic salpingo-oophoritis, cystitis, asymptomatic bacteriuria, chronic and gestational pyelonephtitis, and the extragenital infection focal points that, in turn, cause heavy perinatal complications and consequences (if not detected and treated well in advance). Therefore, this problem is of particular importance since infecting could occur not only in the course of pregnancy, but also prior to it (given a considerable reduction of immunity) [21, 22].

\section{CONCLUSIONS}

A series of recent studies have shown that a part of not developed pregnancies, spontaneous miscarriages and premature deliveries are caused by the infection process focal points in the uterine mucous membrane and cervix due to such agents as chlamydia, mycoplasma, herpes simplex virus, cytomegalovirus etc. Of especial hazard is the fact that in $80 \%$ of cases the urogenital infection proceeds latently, and the female could not even suspect its presence [23-25].

Outlook of further studies: despite the progress achieved during last years in preventing the urogenital mixed infections in females of reproductive age, this problem still remains relevant. Of specific interest is the pre-clinical diagnostics of the above pathology.

\section{REFERENCES/ЛITEPATYPA}

1. Dovlethanova, E.R., Abakarova, P.R.

"Possibility of applying the complex preparations in treating the vulvovaginitis of polymicrobial etiology." Obstetrics and gynecology 4 (2012): 8-11.

Довлетханова, Э.Р.

Возможность применения комплексных препаратов в лечении вульвовагинитов полимикробной этиологии / Э.Р. Довлетханова, П.Р. Абакарова // Акушерство и гинекология. - 2012. - № 4. - С. 8-11.

2. Saghi-Nejad, H., Wasstrman, M., Weidner, W., et al.

"Sexually transmitted diseases and sexual function." Journal of Sexual Medicine 7 (2010): 389-413.

3. Ledger, W. Witkin, S.

Vulvovaginal infection. Manson Publishing Ltd. (2010): 127 p.

4. Markos, A.R

"The concordance of Chlamydia trachomatis genital infection between sexual partners, in the era of nucleic acid testing." Sex Health 2 (2009): 23-4.

World Health Organization.

Global prevalence incidence of selected curable sexually transmitted infections. Geneva. WHO (2012).

6. Pennehouat, G., Joly-Guilou, M.I., Mohseni, H., et al.

"Treatment of genital infections in gynecology." Gynecol Obstet Fertil 30.9 (2009): 744-9.

7. Henry-Suchet, J.

Linfection en gynecologie. Paris (2009): 176 p. 
8. Romashchenko, O.V., Rudenko, A.V., Biloholovska, V.V., et al. "Diagnostics of the urinary tract and genital organs inflammatory diseases in females." In: Collection of scientific works of the Ukrainian Association of Obstetricians and Gynecologists. Kyiv. Intermed (2009) 271-273.

Ромащенко, О.B.

Діагностика запальних захворювань сечовивідних шляхів та геніталій у жінок / O.B. Ромащенко, А.В. Руденко, В.В. Білоголовська та ін. // Збірник наукових праць Асоціації акушерів-гінекологів України. - Київ: Інтермед, 2009. - С. 271-273.

9. Rudenko, A.V., Romashchenko, O.V., Romanenko, A.M., et al. "The role of infectious factors in forming disorders of the family reproductive health." PAG 2 (2009): 65-8.

Руденко, А.В.

Роль інфекційних факторів у формуванні порушень репродуктивного здоров'я сім'ї / А.В. Руденко,

0.В. Ромащенко, А.М. Романенко та ін. // ПАГ. - 2009. № 2. - C. 65-68.

10. Workowski, K.A., Berman, S.M.

"Sexually transmitted diseases treatment guidelines." MMWR Recomm Rep 55 (2009): 1-94.

11. Romashchenko, 0.V.

"Revaluation of approaches to the diagnostics and treatment of the genital organs inflammatory diseases caused by the Chlamydia infection taking into account European recommendations." Reproductive endocrinology 1.3 (2012): $51-8$.

Ромащенко, О.В.

Переоценка подходов к диагностике и лечению воспалительных заболеваний гениталий, обусловленных хламидийной инфекцией, с учетом Европейских рекомендаций / О.В. Ромащенко // Репродуктивная эндокринология. - 2012. - № 1 (3). - С. 51-58.

12. Larsen, B.

"Microbiology of the female genital tract." In: Obstetric and Gynecologic Infections Diseases, ed. by J. Pastorek. New York. Raven Press (2009): 11-26.

13. Eschenbach, D.A., Davick, P.R., Willams, D.L., et al. "Prevalence of hydrogen peroxide-producing Lactobacillus species in normal women and women with bacterial vaginosis." J Clin Microbiol 27 (2010): 251-6.

14. Penney, G.C., Thompson, M., Norman, J., et al. "A randomized comparison of strategies for reducing infective complications of induced abortion." Br J Obstet Gynecol 105 (2010): 599-604.

15. Evidentiary medicine. Annual international handbook. Issue 2, part 5. Translated from English. Moscow. Media Sphere (2013).

Доказательная медицина: ежегодный международный справочник.

Пер. с англ. Вып. 2, часть 5. - Москва: Медиа Сфера, 2013.

16. Mazzulli, T.

"Resistance trends in urinary tract pathogens and impact on management."

J Urol 168.4.2 (2012): 1720-2.

17. Romashchenko, O.V., Vozianova, S.V., Rudenko, A.V.

"Treatment of PID caused by the mixed infection." Women health 6 (2016): 34-42.

Ромащенко, 0.B.

Лікування запальних захворювань органів малого тазу, спричинених мікст-інфекцією / О.В. Ромащенко,

С.В. Возіанова, А.В. Руденко // Здоровье женщины. 2016. - №6. - C. 34-42.

18. Lopatkin, N.A., Derevianko, I.I., Nefedova, L.A. "Etiological structure and treatment of infectious inflammatory complications in the urological practice." In: Materials of the Plenum of Russian Urological Society. Kirov (2011): 5-29.
Лопаткин, Н.A.

Этиологическая структура и лечение инфекционновоспалительных осложнений в урологической практике / Н.А. Лопаткин, И.И. Деревянко, Л.А. Нефедова // Материалы Пленума Российского общества урологов. Киров: 2011. - C. 5-29.

19. Savicheva, A.M., Bashmakova, M.A.

Urogenital chlamydiosis in females and its consequences.

Nizhniy Novgorod (2010): 3-89.

Савичева, А.М.

Урогенитальный хламидиоз у женщин и его последствия /

А.М. Савичева, М.А. Башмакова. - Н. Новгород: 2010. C. 3-89.

20. Stamm, W.E., et al.

"Management of urinary tract infections in adults." N Engl J Med 329.18 (2012): 1328-34.

21. Lapach, S.N., Chubenko, A.V., Babich, P.N.

Statistical methods in medical and biological studies using

Excel. Kyiv. Morion (2010): $319 p$.

Лапач, C.H.

Статистические методы в медико-биологических исследованиях с использованием Excel / С.Н. Лапач, А.В. Чубенко, П.Н. Бабич. - К.: Морион, 2010. - 319 с.

22. Johannisson, A., Festin, $R$.

"Phenotype transition of CD4+T cells from CD45RO is accompanied by cell activation and proliferation." Cytometry 19 (2013): 343-52.

23. Radzinsky, V.E., Ordiants, I.M., Pobedinskaya, O.S.,

Buyanova, N.V.

"Modern aspects of disbiotic disorder correction in the gynecological practice." Obstetrics and gynecology 2 (2013): 72-6. Радзинский, B.E.

Современные аспекты коррекции дисбиотических нарушений в гинекологической практике /

В.Е. Радзинский, И.М. Ордиянц, О.С. Побединская,

Н.В. Буянова // Акушерство и гинекология. - 2013. -

№ 2. - C. $72-76$.

24. Kisina, V.I.

"Vaginal infections: clinical value and treatment." Dermatovenerology and dermatocosmetology 1 (2011):

28-33.

Кисина, В.И.

Вагинальные инфекции: клиническое значение и лечение / В.И. Кисина // Дерматовенерология и дерматокосметология. - 2011. - № 1. - С. 28-33.

25. Blinov, D.V.

"Vaginal infections - from diagnostics to rational complex therapy." Obstetrics, gynecology and reproduction 5.4 (2011): 44-7.

Блинов, Д.В.

Вагинальные инфекции - от диагностики к рациональной комплексной терапии / Д.В. Блинов // Акушерство,

гинекология и репродукция. - 2011. -№ 5 (4). - С. 44-47.

26. Gupta, K., Trautner, B.W.

"Diagnosis and management of recurrent urinary tract infections in non-pregnant women." BMJ 346 (2013): $\{3140$. DOI: 10.1136/bmj.f3140

27. Rossignol, L., Vaux, S., Maugat, S., et al.

"Incidence of urinary tract infections and antibiotic resistance in the outpatient setting: a cross-sectional study (n.d.)." Infection 45.1 (2017): 33-40. DOI: 10.1007/s15010-016-0910-2

28. Hooton, T.M.

"Uncomplicated Urinary Tract Infection." N Engl J Med 366

(2012): 1028-37. DOI: 10.1056/NEJMcp1104429

29. Keren, R., Shaikh, N., Pohl, H., et al.

"Risk Factors for Recurrent Urinary Tract Infection and Renal

Scarring." Pediatrics 136 (2015): e13-21. D0l: 10.1542/

peds.2015-0409
30. Guglietta, A.

"Recurrent urinary tract infections in women: risk factors, etiology, pathogenesis and prophylaxis." Future Microbiol 12 (2017): 239-46. DOI: 10.2217/fmb-2016-0145

31. Nicole, L.E.

"Urinary Tract Infections in the Older Adult." Clin Geriatr med 32 (2016): 523-38. D0l: 10.1016/j.cger.2016.03.002

32. Horner, P.J., Blee, K., Falk, L., et al.

"European guideline on the management of non-gonococcal urethritis." Int J STD AIDS 27 (2016): 928-37. D01:

$10.1177 / 0956462416648585$

33. Horner, P.J., Blee, K., O'Mahony, C., et al.

"UK National Guideline on the management of nongonococcal urethritis." Int J STD AIDS 27 (2016): 85-96. D0I: 10.1177/0956462415586675

34. Shapiro, T., Dalton, M., Hammock, J., et al.

"The Prevalence of Urinary Tract Infections and Sexually Transmitted Disease in Women with Symptoms of a Simple Urinary Tract Infection Stratified by Low Colony Count Criteria." Acad Emerg Med 12 (2009): 38-44. D0l: 10.1111/j.1553-

2712.2009.tb01476.x

35. Bader, M.S., Loeb, M., Brooks, A.A.

"An update on the management of urinary tract infections in the era of antimicrobial resistance." Postgrad Med 129 (2017): 242-58. DOI: 10.1080/00325481.2017.1246055

36. Al Majid, F., Buba, F.

"The Predictive and Discriminant Values of Urine Nitrites in Urinary Tract Infection." Biomedical Research 21.3 (2010).

37. Tomas, M.E., Getman, D., Donskey, C.J., Hecker, M.T. "Overdiagnosis of Urinary Tract Infection and Underdiagnosis of Sexually Transmitted Infection in Adult Women Presenting to an Emergency Department." J Clin Microbiol 53 (2015): 2686-92. D0l: 10.1128/JCM.00670-15

38. Dyar, 0.J., Huttner, B., Schouten, J., Pulcini, C.

"What is antimicrobial stewardship?" Clin Microbiol Infect 23 (2017): 793-8. D0l: 10.1016/J.CMI.2017.08.026

39. Teede, H.J., Misso, M.L., Costello, M.F., et al.

"Recommendations from the international evidence-based guideline for the assessment and management of polycystic ovary syndrome." Hum Reprod 33 (2018): 1602-18. D0l: 10.1093/humrep/dey256

40. Kauffman, C.A.

"Diagnosis and Management of Fungal Urinary Tract Infection." Infect Dis Clin North Am 28 (2014): 61-74. D0l: 10.1016/j. idc.2014.09.004

41. Hilt, E.E., McKinley, K., Pearce, M.M., et al.

"Urine Is Not Sterile: Use of Enhanced Urine Culture Techniques To Detect Resident Bacterial Flora in the Adult Female Bladder." J Clin Microbiol 52 (2014): 871-6. D0l: 10.1128/ JCM.02876-13

42. LaRocco, M.T., Franek, J., Leibach, E.K., et al. "Effectiveness of Preanalytic Practices on Contamination and Diagnostic Accuracy of Urine Cultures: a Laboratory Medicine Best Practices Systematic Review and Meta-analysis." Clin Microbiol Rev 29 (2016): 105-47. D0l: 10.1128/ CMR.00030-15 


\section{PROBLEM OF UROGENITAL MIXED INFECTIONS IN REPRODUCTIVE AGED WOMEN IN CURRENT GYNECOLOGY}

\section{Literature review}

N.Y. Bysaha, PhD, associate professor of the Obstetrics and Gynecology Department, Medical Faculty of the Uzhgorod National University; obstetrician-gynecologist of the gynecological department, Uzhgorod Regional Hospital, Uzhgorod

0.0. Korchynska, MD, professor of the Obstetrics and Gynecology Department, Medical Faculty of the Uzhgorod National University, Uzhgorod

A tendency of annual growth in inflammatory diseases of female genital organs is being observed now, and these diseases have a long-term recrudescent character with the inflammatory process chronization. Physicians of all specialties in a world medical practice prefer the term "pelvic inflammatory disease".

Goal of this literature review was to generalize the up-to-date data on the problem of the urogenital mixed infections in women of reproductive age. Reviewing both foreign and domestic literature sources published in recent 10 years on the problem of urogenital mixed infections in women of reproductive age.

Pelvic inflammatory diseases is a group of diseases (independent nosological entities) of the upper region of female reproductive tract that combine endometritis, salpingitis, 0ophoritis, tuboovarian abscess and pelvis peritonitis. The highest it risks was noticed among the younger women of reproductive age (below 25) with unprotected sexual relationships and numerous sexual partners.

Three different levels of genital organ disorders are distinguished dependent of the infection process localization: the lower level, the upper level and the mixed one, i.e. the combination of the lower and the upper levels. Vulvitis, vulvovaginitis, vaginitis and endocervicitis belong to the lower level of genital organ disorders, salpingo-0ophoritis, endometritis, metroendometritis and pelvioperitonitis belong to the upper one, while the mixed level includes disorders of both upper and lower genital tracts. Considerable anatomic and functional changes in pelvic organs are formed in 1-2 years from the moment of the genital inflammatory disease beginning and traditionally are not detected at the initial stages of their progress, being, in most cases, accompanied by the reproductive and sexual health disorders.

The mucous membranes of urinary tracts, vagina and uterine cervix are populated by various microorganisms that are in a constant antagonism or synergism with each other. Colonization resistance of the vagina and urinary tract mucous membranes provides the natural microbiocenosis stability, prevents pathogenic microorganism colonization and active reproduction of the conditionally pathogenic microflora.

Keywords: urogenital mixed infection, conditionally pathogenic microflora, pelvic inflammatory diseases.

\section{ПРОБЛЕМА УРОГЕНІТАЛЬНИХ МІКСТ-ІНФЕКЦІЙ У ЖІНОК РЕПРОДУКТИВНОГО ВІКУ В СУЧАСНІЙ ГІНЕКОЛОГІЇ Огляд літератури}

Н.Ю. Бисага, К. мед. Н., доцент кафедри акушерства та гінекології медичного факультету ДВНЗ «Ужгородський національний університет»; лікар акушер-гінеколог гінекологічного відділення КЗ «Ужгородська районна лікарня», м. Ужгород

0.0. Корчинська, д. мед. Н., професор кафедри акушерства та гінекології медичного факультету ДВНЗ «УЖгородський національний університет», м. Ужгород

На даний час спостерігається тенденція до щорічного зростання запальних захворювань жіночих статевих органів, які нерідко мають тривалий рецидивуючий перебіг із хронізацією запального процесу. У світовій медичній практиці лікарі всіх спеціальностей віддають перевагу терміну «запальні захворювання органів малого таза».

Мета огляду літератури - узагальнення наявних даних щодо проблеми урогенітальних мікст-інфекцій у жінок репродуктивного віку. Виконаний огляд іноземних та вітчизняних джерел літератури за останні 10 років щодо проблеми урогенітальних мікст-інфекцій у даного контингенту жінок.

Запальні захворювання органів малого таза - це група захворювань (самостійних нозологічних форм) верхнього відділу репродуктивного тракту жінки, що поєднують ендометрит, сальпінгіт, оофорит, тубооваріальний абсцес та тазовий перитоніт. Найвищий ризикїх розвитку відзначено серед жінок молодшого репродуктивного віку - до 25 років, із незахищеними статевими стосунками та численними статевими партнерами.

Залежно від локалізації інфекційного процесу розрізняють 3 рівні ураження статевих органів: нижній, верхній та змішаний - поєднання нижнього та верхнього рівнів ураження. До нижнього рівня ураження статевих органів відносяться вульвіт, вульвовагініт, вагініт, ендоцервіцит, до верхнього - сальпінгоофорит, ендометрит, метроендометрит, пельвіоперитоніт, до змішаного - ураження верхніх та нижніх статевих шляхів. Значні анатомо-функціональні зміни з боку органів малого таза формуються через $1-2$ роки 3 моменту виникнення запального захворювання статевих органів і традиційно не діагностуються на початкових етапах їхнього розвитку, у більшості випадків супроводжуючись порушеннями репродуктивного та сексуального здоров'я.

Слизові оболонки сечовивідних шляхів, піхви, шийки матки заселені популяціями різних мікроорганізмів, які перебувають в постійному антагонізмі або синергізмі між собою. Колонізаційна резистентність піхви і слизових оболонок сечовивідних шляхів забезпечує стабільність природного мікробіоценозу, попереджає заселення патогенними мікроорганізмами і активне розмноження умовно-патогенної мікрофлори.

Ключові слова: урогенітальна змішана інфекція, умовно-патогенна мікрофлора, запальні захворювання органів малого таза.

\section{ПРОБЛЕМА УРОГЕНИТАЛЬНЫХ МИКСТ-ИНФЕКЦИЙ У ЖЕНЩИН РЕПРОДУКТИВНОГО ВОЗРАСТА В СОВРЕМЕННОЙ ГИНЕКОЛОГИИ Обзор литературы}

Н.Ю. Бисага, к. мед. Н., доцент кафедры акушерства и гинекологии медицинского факультета ГВУЗ «Ужгородский национальный университет»; врач акушер-гинеколог гинекологического отделения КЗ «УЖгородская районная больница», г. Ужгород

0.А. Корчинская, д. мед. Н., профессор кафедры акушерства и гинекологии медицинского факультета ГВУЗ «УЖгородский национальный университет», г. Ужгород

В настоящее время наблюдается тенденция к ежегодному росту воспалительных заболеваний женских половых органов, которые нередко имеют длительное рецидивирующее течение с хронизацией воспалительного процесса. В мировой медицинской практике врачи всех специальностей предпочитают термин «воспалительные заболевания органов малого таза».

Цель обзора литературы - обобщение имеющихся данных по проблеме урогенитальных микст-инфекций у женщин репродуктивного возраста. Выполнен обзор зарубежныхи отечественных источников литературы за последние 10 лет по проблеме урогенитальных микст-инфекций данного контингента женщин.

Воспалительные заболевания органов малого таза - это группа заболеваний (самостоятельных нозологических форм) верхнего отдела репродуктивного тракта женщины, сочетающие эндометрит, сальпингит, оофорит, тубоовариальный абсцесс и тазовый перитонит. Наиболее высокий риск их развития отмечен среди женщин более молодого репродуктивного возраста - до 25 лет, с незащищенными половыми отношениями и многочисленными половыми партнерами.

В зависимости от локализации инфекционного процесса различают 3 уровня поражения половых органов: нижний, верхний и смешанный - сочетание нижнего и верхнего уровней поражения. К нижнему уровню поражения половых органов относятся вульвит, вульвовагинит, вагинит, эндоцервицит, к верхнему - сальпингоофорит, эндометрит, метроэндометрит, пельвиоперитонит, к смешанному - поражение верхних и нижних половых путей. Значительные анатомо-функциональные изменения со стороны органов малого таза формируются через 1-2 года с момента возникновения воспалительного заболевания половых органов и традиционно не диагностируются на начальных этапах их развития, в большинстве случаев сопровождаясь нарушениями репродуктивного и сексуального здоровья.

Слизистые оболочки мочевыводящих путей, влагалища, шейки матки заселены популяциями различных микроорганизмов, которые находятся в постоянном антагонизме или синергизме между собой. Колонизационная резистентность влагалища и слизистых оболочек мочевыводящих путей обеспечивает стабильность природного микробиоценоза, предупреждает заселение патогенными микроорганизмами и активное размножение условно-патогенной микрофлоры.

Ключевые слова: урогенитальная смешанная инфекция, условно-патогенная микрофлора, воспалительные заболевания органов малого таза. 